\title{
MOLECULAR PARAMETERS AND THE ANTIMICROBIAL ACTIVITY OF FUNCTIONAL DERIVATIVES OF N-,R-AMINES
}

\author{
M.Yu.Golik, O.S.Kryskiv, K.I.Dudka, O.V.Kolisnyk \\ National University of Pharmacy
}

Key words: molecular descriptors; "drug-likeness" concept; Lipinski rules; antimicrobial activity

To check for conformity of the "drug-likeness" concept in the series of functional derivatives of N-Ramines their physicochemical parameters have been calculated using the ChemBio3D Ultra 14.0 software; they determine bioavailability according to Lipinski rules. The abovementioned derivatives are shown to be promising for further study. Using the correlation and regression analysis the quantitative "structure - antimicrobial activity" relationship has been determined among some N-R-amines; it can be useful while searching biologically active substances in the given series.

Determination of the «structure - action» relationship is widely used in modern chemistry of biologically active substances to predict their possible pharmacological activity [3].

The methods for determining the quantitative "structure - activity" relationship (QSAR) allow assessing the influence of the chemical structure on the biological activity of molecules using computer-aided molecular design by constructing mathematical models, and it is much better than carrying out the experiment. In addition, on the basis of the models obtained there is a possibility to consider properties of the new compounds synthesized and predict new structures with desirable properties $[2,15]$.

The "drug-likeness" concept is used when developing medicines to provide the conformity of a potential biologically active substance to certain criteria, in particular it should be bioavailable. The chemical structure is estimated in advance before carrying out the synthesis and biological testing, primarily tests for solubility in water and fats.

The number of donors of hydrogen bonds and the presence of the alkyl side chains in the molecule affect the parameter mentioned. A small number of donors leads to the low solubility in water and a slow absorption and action. Too many hydrogen bond donors lead to low lipid solubility, therefore, the molecule cannot penetrate through the cell membrane. The molecular weight also significantly affects transmembrane transport: the less it is, the better (most of the known drugs have the molecular weight from 200 to 600 units, in particular <500) $[6,13]$.

Based on the observation that most drugs are relatively small and moderately lipophilic molecules Chris Lipinski introduced the famous Rule of five in 1997 [12]. It describes the molecular properties, which are important for pharmacokinetics of the drug in the body, including absorption, distribution, metabolism, and excretion ("ADME") [10], however, it does not predict the presence of the pharmacological activity in compounds.

The traditional method of "drug-likeness" assessment is to check for conformity to Lipinski rules, which consider the number of hydrophilic and hydrophobic groups, molecular weight and lipophilicity [11]. According to these rules the molecule should have a value (not more): $\log \mathrm{P}-5.6$, molecular weight (MW) - $480 \mathrm{~g} / \mathrm{mol}$, molar refraction (MR) $-130 \mathrm{~cm}^{3}$, and consist of 20 to 70 atoms [17]. Molar refraction is the volume of all molecules contained in one mole of a substance, characterizes the ability of all electrons located in it to polarization and almost independent from temperature and the physical state of the substance. This property allows using it successfully for determining dipole moments of molecules, studying of the molecular structure, forming hydrogen bonds, etc. [14].

The aim of this work is to determine conformity of a number of functional derivatives of N-R-amines to the "drug-likeness" concept and identify the quantitative "structure - microbiological activity" relationship.

\section{Materials and Methods}

Previously [8] the microbiological activity of N-Ramines 1-20 (Tab. 1) was studied, the values of the distribution coefficients for these compounds were calculated [9]. Using the values obtained the possible quantitative relationships were determined, and the "structureaction" relationships in the given series compared to the data of the biological activity experimentally obtained were discussed.

To check for conformity to Lipinski rules the physicochemical parameters determining bioavailability of $\mathrm{N}$ $\mathrm{R}$-amines 1-20 were calculated using the ChemBioOffice 2014 software, in particular ChemBio3D Ultra 14.0 [5]; statistical processing of the results was carried out using the STATISTIKA 8 program [16] (Tab. 2). According to the requirements of mathematical statistics the correlation coefficient indicates the neighbouring relationship between the signs: at values less than 0.3 - the relationship is absent, in the range of $0.3-0.7-$ it is medium, over 0.7 - it is strong [17].

Molar refraction is an important physicochemical parameter, which allows to assess the complex of the molecule properties and its potential bioavailability. Therefore, the next logical step was to determine possible correlations and quantitative ratios of the data of the biological activity experimentally obtained with the values of MR calculated (Tab. 1, 2). 
Table 1

Data of the antimicrobial activity of compounds 1-20 [8]

\begin{tabular}{|c|c|c|c|c|c|c|}
\hline \multirow[b]{2}{*}{ No. } & \multicolumn{6}{|c|}{$\begin{array}{l}\text { The inhibition zone diameter, } \mathrm{mm} \\
\text { (the average value) }\end{array}$} \\
\hline & 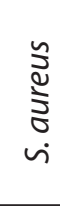 & نَ & $\begin{array}{l}\frac{n}{5} \\
\vdots \\
\frac{0}{3} \\
\vdots \\
0\end{array}$ & 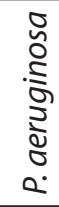 & 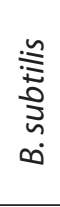 & 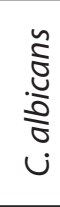 \\
\hline 1 & 10 & 10 & 10 & 10 & 10 & 10 \\
\hline 2 & 10 & 10 & 10 & 10 & 10 & 10 \\
\hline 3 & 10 & 10 & 10 & 10 & 10 & 10 \\
\hline 4 & 10 & 10 & 10 & 10 & 10 & 10 \\
\hline 5 & 12 & 12 & 10 & 10 & 10 & 10 \\
\hline 6 & 13 & 12 & 10 & 10 & 10 & 10 \\
\hline 7 & 15 & 14 & 10 & 10 & 15 & 14 \\
\hline 8 & 10 & 10 & 10 & 10 & 10 & 10 \\
\hline 9 & 20 & 15 & 20 & 18 & 21 & 14 \\
\hline 10 & 15 & 15 & 13 & 10 & 10 & 15 \\
\hline 11 & 10 & 10 & 10 & 10 & 10 & 10 \\
\hline 12 & 20 & 18 & 20 & 20 & 17 & 15 \\
\hline 13 & 20 & 18 & 19 & 20 & 25 & 20 \\
\hline 14 & 21 & 17 & 18 & 20 & 25 & 20 \\
\hline 15 & 40 & 26 & 23 & 22 & 39 & 18 \\
\hline 16 & 40 & 25 & 22 & 20 & 39 & 20 \\
\hline 17 & 42 & 25 & 22 & 23 & 39 & 19 \\
\hline 18 & 22 & 19 & 18 & 18 & 24 & 16 \\
\hline 19 & 10 & 10 & 10 & 10 & 10 & 10 \\
\hline 20 & 10 & 10 & 10 & 10 & 10 & 10 \\
\hline
\end{tabular}

Scatterplot: MR vs. S. aureus S. aureus $=32,540-5,217 * \mathrm{MR}$ Correlation: $r=-, 6102$

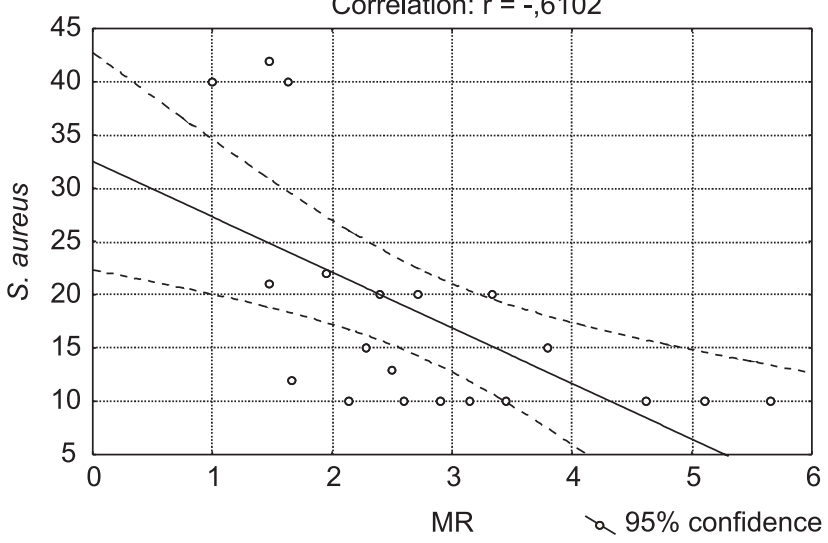

Fig. 1. Correlation of the antimicrobial action against $S$. aureus and MR.

\section{Results and Discussion}

All of the compounds studied due to a combination of the physicochemical properties meet the requirements for new BAS at the stage of testing their biological activity (corresponding to Lipinski rules).

All in all, 20 compounds were included in the statistical sample. During statistical processing of the research results in the analysis of the sample with the length of 20 cases the values of Pearson correlation coefficients
Scatterplot: MR vs. E. coli

E. coli $=22,783-2,846$ * MR Correlation: $r=-, 6341$

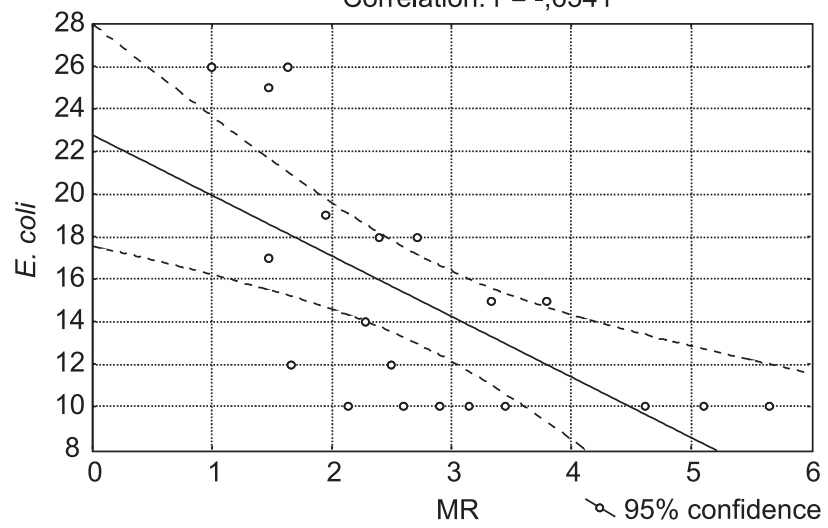

Fig. 2. Correlation of the antimicrobial action against $E$. coli and MR.

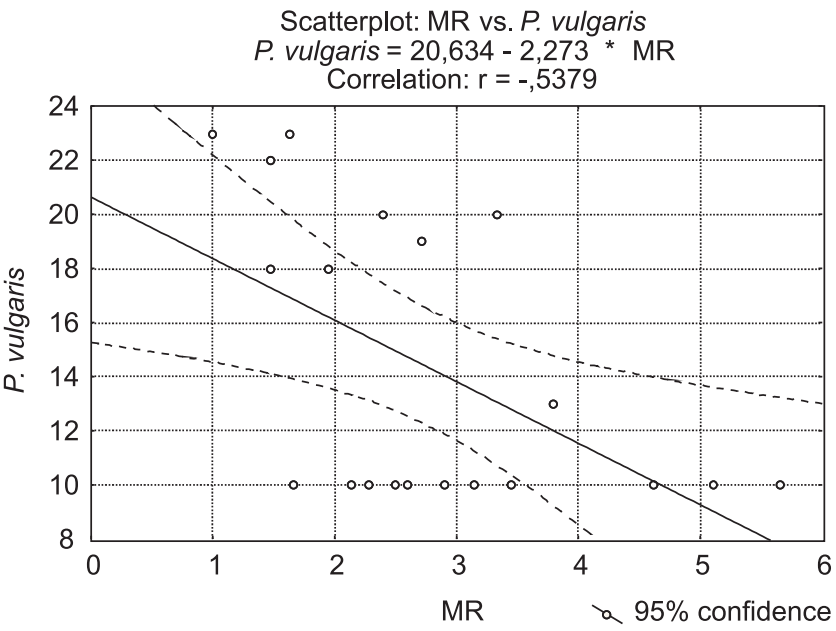

Fig. 3. Correlation of the antimicrobial action against $P$. vulgaris and MR.

Scatterplot: MR vs. $P$. aeruginosa

$P$. aeruginosa $=20,969-2,447$ * MR Correlation: $r=-, 5736$

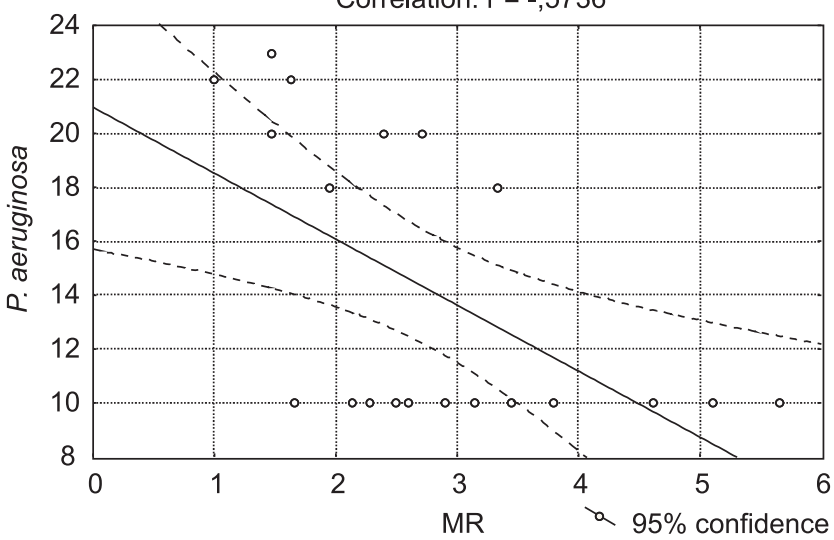

Fig. 4. Correlation of the antimicrobial action against $P$. aeruginosa and MR.

more than $0.40(p \leq 0.05)$ were considered to be statistically significant $[1]$.

The dependence of the microbiological action of compounds 1-20 on MR has a nonlinear character, and reaches maximum values for compounds, which MR value is in the range close to the average value (1.63-2.80) (Tab. 1, 2). The minimum values of activity were observed for compounds with the MR values from 2.90 to 4.61. The maximum activity of all compounds tested were 
Table 2

The calculated physicochemical parameters of functional derivatives of $\mathrm{N}$-R-amines

\begin{tabular}{|c|c|c|c|c|c|c|}
\hline \multirow[b]{2}{*}{ No. } & \multirow[b]{2}{*}{ Compound } & \multicolumn{5}{|c|}{ Parameters } \\
\hline & & $\mathrm{MW}, \mathrm{g} / \mathrm{mol}$ & $\mathrm{MR}, \mathrm{cm}^{3}$ & AlogPs [9] & $\begin{array}{c}\text { The number } \\
\text { of acceptors of } \\
\mathrm{H} \text {-bond }\end{array}$ & $\begin{array}{c}\text { The number } \\
\text { of donors of } \\
\mathrm{H} \text {-bond }\end{array}$ \\
\hline 1 & $\mathrm{CH}_{3} \mathrm{NH}_{2}$ & 31.06 & 1.00 & -1.06 & 1 & 1 \\
\hline 2 & $\mathrm{CH}_{3} \mathrm{CH}_{2} \mathrm{NH}_{2}$ & 45.08 & 1.47 & -0.2 & 1 & 1 \\
\hline 3 & $\mathrm{HOCH}_{2} \mathrm{CH}_{2} \mathrm{NH}_{2}$ & 61.08 & 1.63 & -1.53 & 2 & 2 \\
\hline 4 & $\left(\mathrm{CH}_{3}\right)_{2} \mathrm{NH}_{2}$ & 45.08 & 1.47 & -0.53 & 1 & 1 \\
\hline 5 & $\left(\mathrm{CH}_{3} \mathrm{CH}_{2}\right)_{2} \mathrm{NH}$ & 73.14 & 2.40 & 0.76 & 1 & 1 \\
\hline 6 & $\left(\mathrm{HOCH}_{2} \mathrm{CH}_{2}\right)_{2} \mathrm{NH}$ & 105.14 & 2.71 & -1.41 & 3 & 3 \\
\hline 7 & $\left(\mathrm{CH}_{3}\right)_{3} \mathrm{~N}$ & 59.11 & 1.94 & -0.14 & 0 & 1 \\
\hline 8 & $\left(\mathrm{CH}_{3} \mathrm{CH}_{2}\right)_{3} \mathrm{~N}$ & 101.19 & 3.33 & 1.57 & 1 & 0 \\
\hline 9 & $\left(\mathrm{HOCH}_{2} \mathrm{CH}_{2}\right)_{3} \mathrm{~N}$ & 149.19 & 3.79 & -1.38 & 4 & 3 \\
\hline 10 & $\left(\mathrm{CH}_{3}\right)_{4} \mathrm{~N}^{+}$ & 74.15 & 2.49 & -1.59 & 0 & 0 \\
\hline 11 & $\mathrm{OH}$ & 75.07 & 1.66 & -3.34 & 2 & 2 \\
\hline 12 & & 105.09 & 2.28 & -3.24 & 3 & 3 \\
\hline 13 & & 135.12 & 2.90 & -1.76 & 4 & 3 \\
\hline 14 & & 150.15 & 3.45 & -1.94 & 3 & 3 \\
\hline 15 & & 89.09 & 2.13 & -3.06 & 2 & 2 \\
\hline 16 & & 103.12 & 2.59 & -1.70 & 2 & 1 \\
\hline 17 & & 118.16 & 3.14 & -1.90 & 1 & 1 \\
\hline 18 & & 163.18 & 4.61 & 1.39 & 2 & 1 \\
\hline 19 & & 179.22 & 5.10 & -0.32 & 2 & 1 \\
\hline 20 & & 194.25 & 5.65 & -1.40 & 1 & 1 \\
\hline & Limits & $31.06-194.25$ & $1.00-5.65$ & $-3.34-1.57$ & $0-4$ & $0-3$ \\
\hline & erage value & 102.86 & 2.79 & -1.14 & 1.8 & 1.55 \\
\hline$M$ & n permitted value & 460 & 130 & 5.6 & 5 & 10 \\
\hline
\end{tabular}

observed against gram-positive microorganisms (B. subtilis and $S$. aureus), the less activity - for gram-negative microorganisms (E. coli, $P$. vulgaris, $P$. aeruginosa) and fungi (C. albicans). It may be associated with peculiarities of the cell wall structure [4].

Analysis of the results of statistical processing indicates that the MR values calculated correlate satisfac- torily $(\%$, the negative values of the correlation coefficients) with the experimental data of the antimicrobial activity of compounds $\mathbf{1 - 2 0}$ against $S$. aureus $(\mathrm{r}=-0.6102)$, E. coli $(\mathrm{r}=-0.6341)$, P. vulgaris $(\mathrm{r}=-0.5379)$, . aeruginosa $(\mathrm{r}=-0.5736)$, B. subtilis $(\mathrm{r}=-0.6117)$ and $C$. albicans $(\mathrm{r}=-0.5526)$ and are statistically significant (Fig. 1-6). 


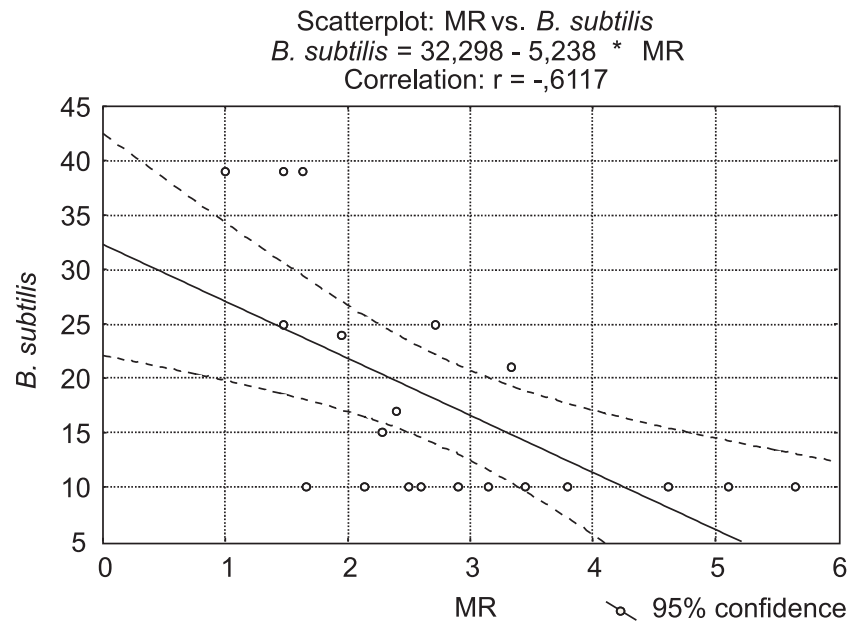

Fig. 5. Correlation of the antimicrobial action against $B$. subtilis and MR.

The mentioned combinations of Pearson correlation coefficients and importance factors indicate the accuracy of graphs and equations given in Fig. 1-6.

Therefore, previously expressed views [8] concerning the presence of the "structure - action" relationship and the degree of its expression have been quantitatively confirmed by calculation methods. The results obtained allow us to predict the presence and the degree of the biological action expression in the series of N-R-amine derivatives, as well as conduct a targeted search for biologically active substances in the given series.

\section{CONCLUSIONS}

1. Testing of a number of functional derivatives of N-R-amines for conformity of the "drug-likeness" concept has been conducted. The results obtained have shown that the compounds can be recommended for further study

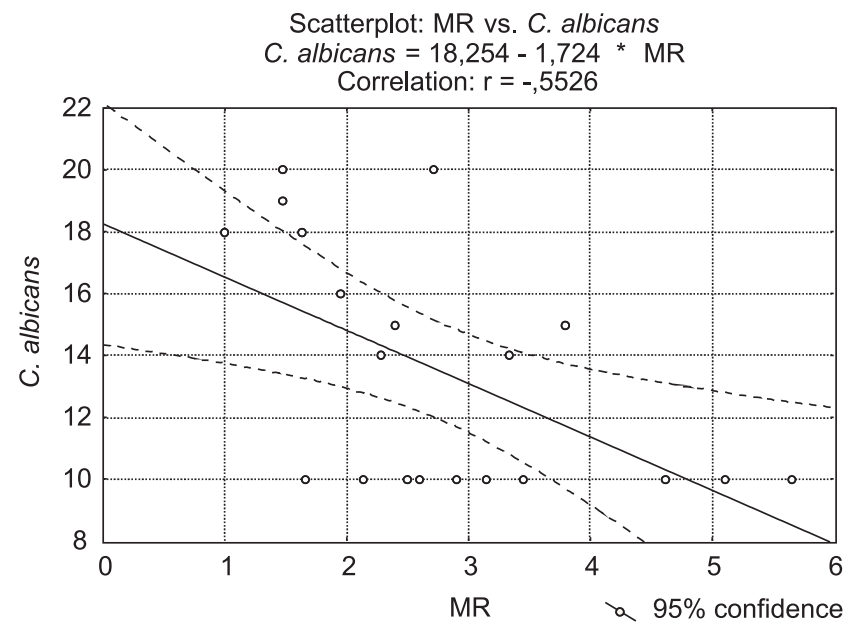

Fig. 6. Correlation of the antimicrobial action against C. albicans and MR.

as those that have favourable physicochemical parameters according to Lipinski rules.

2. To determine the quantitative "structure - action" relationships the correlation and regression analysis of the MR values calculated, as well as the results of the experimental studies of the antimicrobial activity of the compounds under research has been carried out.

3. Statistically significant values of the MR index correlation with the values of the antimicrobial action of N-R-amine derivatives against $S$. aureus, E. coli, P. vulgaris, $P$. aeruginosa, B. subtilis and C. Albicans have been found, and it has quantitatively confirmed the assumptions previously expressed concerning the presence of the "structure - action" relationship in the given series of compounds and the degree of its expression.

\section{REFERENCES}

1. Гублер Е.В., Генкин А.А. Применение непараметрических критериев статистики в медико-биологических исследованиях. - Л.: Медиџина, 1973. - $141 \mathrm{c.}$

2. Anamika S., Rajeev S. // The Open Bioinformatics J. - 2013. - Vol. 7. - P. 63-67.

3. Bickerton G.R. // Nat. Chem. - 2012. - Vol. 4. - P. 90-98.

4. Brock Biology of Microorganisms / M.Madigan, J.Martinko, D.Stahl, D.Clark. 13-th Ed. Pearson Education.: 2012. $-1155 \mathrm{p}$

5. ChemOffice Professional [Electronic resource] (viewed on March 20, 2016). - Mode of access: https://www. cambridgesoft.com/Ensemble_for_Chemistry/ChemOffice/ChemOfficeProfessional/ - Title from the screen.

6. Duffy F.J., Devocelle M., Shields D.C. Computational approaches to developing short cyclic peptide modulators of protein-protein interactions / In P.Zhou, J.Huang. Methods in molecular biology. Computational Peptidology. - New York: Humana Press, 2015. - 250 p.

7. Fujita T. // QSAR. - 1997. - Vol. 16. - P. 107-112.

8. Golik M.Yu., Komissarenko N.A., Leonova S.G. et al. // Biсник фармаціï. - 2015. - №2 (82). - C. 66-69.

9. Golik M.Yu., Kryskiv O.S., Komissarenko A.M. et al. // Biсник фармаціï. - 2016. - №1 (85). - C. $19-23$.

10. Kerns E., Di L. Drug-like properties: concepts, structure design and methods: from ADME to toxicity optimization. - Academic Press, 2008. - 526 p.

11. Leo A., Hansch C., Elkins D. // Chem Rev. - 1971. - Vol. 71, №6. - P. 525-616.

12. Lipinski C.A. // Technol. - 2004. - Vol. 1, №4. - P. 337-341.

13. Lipinski C.A., Lombardo F., Dominy B.W. et al. // Adv. Drug Deliv. Rev. - 2001. - Vol. 46, №1-3. - P. 3-26.

14. Padrón J.A., Carrasco I.R., Pellón R.F. // J. Pharm. Pharmac. Sci. - 2002. - №5 (3). - P. $258-266$. 
15. Raevsky O.A., Grigor'ev V.Y., Liplavskaya E.A. et al. // Mol. Inf. - 2011. - Vol. 30, №2-3. - P. 267-275.

16. Statistica. [Electronic resource] (viewed on March 20, 2016). - Mode of access: http://www.statsoft.com/ Products/STATISTICA-Features/ - Title from the screen.

17. Yusof I., Segall M.D. // Drug Discov. Today. - 2013. - Vol. 18, №13-14. - P. 659-666.

\author{
МОЛЕКУЛЯРНІ ПАРАМЕТРИ ТА АНТИМІКРОБНА АКТИВНІСТЬ ФУНКЦІОНАЛЬНИХ \\ ПОХІДНИХ N-,R-AMIHІB \\ М.Ю.Голік, О.С.Криськів, К.І.Дудка, О.В.Колісник \\ Ключові слова: молекулярні дескриптори; концепція «drug likeness»; правила Ліпінські; \\ антимікробна активність
}

Для перевірки на відповідність концепції «drug likeness» ряду фрункціональних похідних $N$-, $R$ амінів з використанням програми ChemBio3D Ultra 14.0 розраховані їх фрізико-хімічні параметри, які визначають біодоступність згідно з «правилами Ліпінські» та показано, що згадані похідні $\epsilon$ перспективними для подальшого вивчення. З використанням кореляційно-регресійного аналізу встановлено кількісний зв'язок "структура - антимікробна активність» серед деяких $N$-, $R$ амінів, що може бути корисним під час пошуку біологічно активних сполук у зазначеному ряду.

\author{
МОЛЕКУЛЯРНЫЕ ПАРАМЕТРЫ И ПРОТИВОМИКРОБНАЯ АКТИВНОСТЬ \\ ФУНКЦИОНАЛЬНЫХ ПРОИЗВОДНЫХ N-,R-АМИНОВ \\ Н.Ю.Голик, О.С.Крыськив, К.И.Дудка, Е.В.Колесник \\ Ключевые слова: молекулярные дескрипторы; концепция «drug likeness»; правила \\ Липински; противомикробная активность \\ Для проверки на соответствие концепции «drug likeness» ряда фрункциональных производных \\ $N$-,R-аминов с использованием программы ChemBio3D Ultra 14.0 рассчитаны их ффизико-хи- \\ мические параметры, определяющие биодоступность согласно «правил Липински» и по- \\ казано, что указанные производные являются перспективными для дальнейшего изучения. \\ C использованием корреляционно-регрессионного анализа установлена количественная \\ взаимосвязь "структура - антимикробная активность» среди некоторых $N$-, $R$-аминов, что \\ может быть полезным при поиске биологически активных веществ в указанном ряду.
}

